\title{
Cadmium accumulation in coastal demersal fish
}

\author{
Claude Rouleau ${ }^{1, *}$, Charles Gobeil ${ }^{1,2}$, Hans Tjälve ${ }^{3}$ \\ ${ }^{1}$ Institut Maurice-Lamontagne, Ministère des Pêches et Océans, CP 1000, Mont-Joli, Québec G5H 3Z4, Canada \\ ${ }^{2}$ Institut National de la Recherche Scientifique, Centre Eau, Terre et Environnement, 490 avenue de la Couronne, \\ Québec, Québec G1K 9A9, Canada \\ ${ }^{3}$ Swedish University of Agricultural Sciences, Department of Pharmacology and Toxicology, \\ Box 7028, 75007 Uppsala, Sweden
}

\begin{abstract}
The hepatic Cd burden, measured on 291 individuals of 4 species of demersal fish (Gadus morhua, Reinhardtius hippoglossoides, Hippoglossoides platessoides, and Raja radiata), is 2 to 5 times higher in fish from the open Gulf of St. Lawrence than in fish from the St. Lawrence Estuary, $600 \mathrm{~km}$ landward. The higher $\mathrm{Cd}$ burden in the open Gulf is not related to the input of anthropogenic $\mathrm{Cd}$, nor can it be attributed to differences in size, sex, sampling season, or state of health. Rather, the $\mathrm{Cd}$ burden in demersal fish may be related to sediment diagenesis, since the concentration of authigenic $\mathrm{Cd}$ (i.e. Cd minerals formed in the sediments) is higher in the Gulf than in the Estuary, which may lead in turn to Cd-enrichment in sediment-dwelling organisms. Measured Cd burdens in the liver agree with predictions made with a simple biokinetic model that uses realistic estimates of the $\mathrm{Cd}$ content of benthic invertebrates in combination with kinetic parameters determined in $H$. platessoides with in vivo gamma counting. These results strongly suggest that the $\mathrm{Cd}$ content of the diet, rather than of the water phase, determines the hepatic $\mathrm{Cd}$ burden in these demersal fish species.
\end{abstract}

KEY WORDS: Cadmium · Fish · Accumulation · Biogeochemistry · Trophic transfer · Sediment Resale or republication not permitted without written consent of the publisher

\section{INTRODUCTION}

Cadmium content in coastal marine sediments is highly variable due to the precipitation of authigenic cadmium as sulfide (Rosenthal et al. 1995a,b, van Geen et al. 1995, Gobeil et al. 1997a, Morford \& Emerson 1999). Hence, in anoxic basins and in environments with rich organic carbon deposits, sedimentary Cd concentration can reach values up to 1 or 2 orders of magnitude higher than crustal abundance (ca. $0.1 \mu \mathrm{g}$ $\mathrm{g}^{-1}$ ) right at the sediment-water interface (Pedersen et al. 1989). However, sedimentary Cd is usually close to crustal abundance near the sediment-water interface, and increases significantly only below the horizon corresponding to the lower limit of oxygen penetration depth in the sediments (Gobeil et al. 1997a). Although the factors that precisely determine the extent to which a sediment is enriched in authigenic $\mathrm{Cd}$ are not yet fully understood, factors such as fluxes of organic matter at the sea floor, bottom water oxygen concentration, and sedimentation rate appear to be important.

The accumulation of sedimentary $\mathrm{Cd}$ in benthic organisms might be affected by the varying levels of authigenic $\mathrm{Cd}$ in the sediment if high levels occur close to the sediment-water interface, as it is often the case in coastal environments. The view that sedimentary $\mathrm{Cd}$ is mainly bioavailable as a dissolved constituent in porewater, and that dissolved cadmium concentration in porewater controls uptake of this metal by benthic organisms (e.g. Di Toro et al. 1992), is not generally applicable. Indeed, Lee et al. (2000a) concluded that feeding behavior and dietary uptake control the accumulation of $\mathrm{Cd}$ in marine benthic invertebrates (Potamocorbula amurensis, Macoma balthica, Neanthes arenaceodentata, and Heteromastus filiformis), since the levels of $\mathrm{Cd}$ and other metals in the organisms correlated well with those in the sediments, despite the 
presence of a large excess of precipitating acid volatile sulfide (AVS) in the sediments. As suggested in pioneer investigations (Hardisty et al. 1974a,b, Pentreath 1997), if diet is a major vector for the transfer of $\mathrm{Cd}$ to demersal fish, which are predators of benthic organisms, then diagenetic processes leading to the formation of authigenic $\mathrm{Cd}$ sulfide at the vicinity of the sediment-water interface would likely also influence $\mathrm{Cd}$ burdens in fish tissues.

The Laurentian Trough is a $1200 \mathrm{~km}$ long and 300 to 500 m deep basin, which stretches across the Estuary and Gulf of St. Lawrence to the edge of the continental shelf in the northwest Atlantic (Fig. 1). The bottom water in this environment has nearly constant salinity (33 to $34 \%$ ), temperature $\left(2.5\right.$ to $\left.4.5^{\circ} \mathrm{C}\right)$, and $\mathrm{Cd}$ concentrations ( 0.25 to $0.30 \mathrm{nM}$ ) (Cossa 1988, Koutitonsky \& Bugden 1991). The vertical distribution of $\mathrm{Cd}$ in the fine-grained sediments of the Trough is characterized by a sharp concentration gradient at about $1 \mathrm{~cm}$ depth, approximately at the oxygen penetration depth, which results in the downward diffusion of dissolved Cd into the sediments and its subsequent precipitation (Gendron et al. 1986, Gobeil et al. 1987). Moreover, due to the progressive decrease of detrital $\mathrm{Cd}$ flux along the Trough, Cd concentration in the subsurface sediment increases as one moves seaward (Gendron et al. 1986, Sundby et al. 2004). Demersal fish living at both ends of the Laurentian Trough are therefore exposed to different sedimentary Cd levels and speciation. Thus, the Laurentian Trough is an interesting laboratory to investigate the accumulation of $\mathrm{Cd}$ in organisms that feed and spend their life cycle at or near the sedimentwater interface.

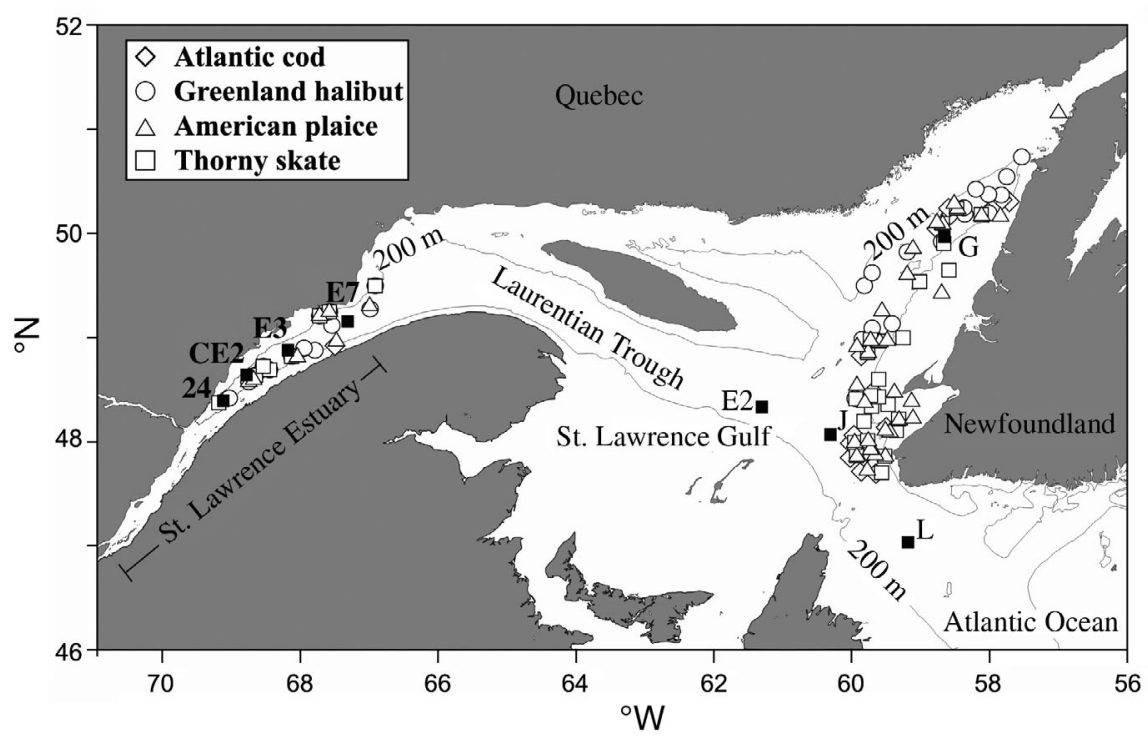

Fig. 1. Location of sediment sampling stations and sites of fish catches. Solid squares: sediment sampling stations with station designation; open symbols: location of fish catches
Here we report results on the hepatic Cd burden in a number of individuals of 4 demersal fish species, the Atlantic cod Gadus morhua, the Greenland halibut Reinhardtius hippoglossoides, the American plaice Hippoglossoides platessoides, and the thorny skate Raja radiata, collected in the open Gulf of St. Lawrence and in the St. Lawrence Estuary. These fish species are good candidates to assess the relationship between $\mathrm{Cd}$ concentrations in sediments and in fish tissues due to a high level of separation among the various stocks (Scott \& Scott 1988, Arthur \& Albert 1993, Swain et al. 1998, Campana et al. 1999). We also present results on the distribution of $\mathrm{Cd}, \mathrm{Mn}$, and AVS in sediment cores from the same regions, as well as data on the biokinetics (Luoma \& Rainbow 2005) of dietary ${ }^{109} \mathrm{Cd}$ in the American plaice, as determined from in vivo gamma counting. Altogether, these results provide an insight into the Cd uptake routes to coastal demersal fish and possible connection with sediment diagenesis.

\section{MATERIALS AND METHODS}

Fish sampling and analysis. Atlantic cod, Greenland halibut, American plaice and thorny skate were collected by bottom trawl in the Estuary and Gulf of St. Lawrence (Fig. 1) in 1993 and 1994 as follows: Atlantic cod were caught in January 1993 and August 1994 in the Gulf, and in June 1994 in the Estuary; Greenland halibut were caught in August 1993; American plaice were caught in January 1993 and August 1994 in the Gulf, and in August 1993 and 1994 in the Estuary; Thorny skate were caught in August 1993 in the Gulf and in January 1993 in the Estuary. Fish were immediately measured, weighed, placed in clean plastic bags, frozen at $-20^{\circ} \mathrm{C}$, and brought back to our laboratory for dissection. Sex was determined and liver was collected and weighed. The hepatosomatic index, HSI (Lambert \& Dutil 1997), and the allometric condition factor, a (Ricker 1975), were calculated following:

$$
a=100 \times W_{\mathrm{So}} S^{-b}
$$$$
\text { and }
$$$$
\mathrm{HSI}=100 \times W_{\mathrm{L}} W_{\mathrm{So}}{ }^{-1}
$$

where $W_{\text {So }}$ is the somatic weight $(g)$, defined as the total weight of the organisms minus the weight of gonads, $W_{\mathrm{L}}$ is the weight of the liver $(\mathrm{g}), S$ is the length of fish $(\mathrm{cm})$, and $b$ is a species-specific coefficient determined by linear regression analysis of $\ln W_{\text {So }}$ versus $\ln S$. 
The liver of each fish was individually homogenized in a Teflon bag, freeze-dried, and mineralized with nitric acid in a microwave oven (Nakashima et al. 1988). Cd concentration was then measured by atomic absorption spectroscopy using a graphite furnace. The detection limit, estimated as 3 times the standard deviation of the analytical blanks, was $0.02 \mathrm{nmol} \mathrm{g}^{-1}$ wet weight (ww). Biological reference material DORM-1 from the National Research Council of Canada, with a certified Cd concentration of $0.77 \pm 0.11 \mathrm{nmol} \mathrm{g}^{-1}$ dry weight $(\mathrm{dw})$, was used to assess the quality of our analyses. The precision was $6 \%$ and analytical accuracy was always within prescribed limits $(n=15)$.

Data of weight, length, HSI, hepatic Cd concentrations, and hepatic $\mathrm{Cd}$ burdens were transformed to the natural logarithm to correct for the non-homogeneity of variances. The Student $t$-test was then used to compare fish from the Estuary and the Gulf.

Sediment sampling and analysis. Undisturbed sediment box-cores were collected at 300 to $500 \mathrm{~m}$ depth in the Laurentian Trough (Fig. 1). The cores were subsampled under inert atmosphere into $1 \mathrm{~cm}$-thick layers from sediment surface down to $10 \mathrm{~cm}$ depth, and then by $2 \mathrm{~cm}$-thick layer from 10 to $20 \mathrm{~cm}$ depth. The sediment samples were then placed in plastic bags and kept frozen at $-20^{\circ} \mathrm{C}$.

Later in the laboratory, sediment aliquots were freeze-dried, homogenized, and completely digested in a microwave oven with a mixture of concentrated nitric, hydrofluoric and perchloric acids (McLaren et al. 1995). The digestates were then analyzed for total $\mathrm{Cd}$ by inductively coupled plasma mass spectrometry (ICP-MS). The overall analytical procedure was verified with the reference sediment BCSS-1 from the National Research Council of Canada. The precision was $\pm 5 \%$, expressed as the coefficient of variation of replicate analyses $(n=10)$ of the reference material. The accuracy was within $10 \%$. Dried sediment aliquots were also analyzed to determine $\mathrm{Cd}$ and $\mathrm{Mn}$ extracted from the sediments during $12 \mathrm{~h}$ with a diluted nitric acid solution (1 N). The precision was better than $5 \%$. AVS was determined in frozen samples according to the procedure of Allen et al. (1993). The detection limit, defined as 3 times the standard deviation of blank samples, was $0.01 \mathrm{\mu mol} \mathrm{g}^{-1} \mathrm{dw}$ and the precision was better than $10 \%$.

Biokinetics of dietary $\mathrm{Cd}$ in American plaice. Six mature female American plaice, weighing 300 to $500 \mathrm{~g}$, were caught in the St. Lawrence Estuary and transferred to $60 \mathrm{l}$ all-glass aquariums $1 \mathrm{wk}$ before the beginning of the experiment. Fish were housed individually in aquaria supplied with aerated filtered flowing seawater and maintained at 5 to $6^{\circ} \mathrm{C}$. The day before the experiment started, supplemented fish food (Provencher et al. 1995) was spiked with radioactive
${ }^{109} \mathrm{Cd}(\mathrm{II})$ (New England Nuclear, $10.5 \mathrm{MBq} \mu \mathrm{mol}^{-1}$, $\left.t_{1 / 2}=462.6 \mathrm{~d}\right)$, thoroughly homogenized with a stainless steel spatula for $5 \mathrm{~min}$, and molded in small balls weighing approximately $0.5 \mathrm{~g}$. The contaminated food was kept at $4^{\circ} \mathrm{C}$ overnight. At Day 0, the fish were anesthetized by placing them in seawater containing $100 \mathrm{mg} \mathrm{l}^{-1}$ of Tricaine (MS-222) for $5 \mathrm{~min}$. They then received 2 balls of contaminated food, which were gently pushed into the stomach with a glass rod. Radioactivity of fish was measured immediately after this feeding and they were returned to their aquarium. Cd dose administered was $44 \mathrm{nmol}$ per fish $(5 \mu \mathrm{g}, 0.46 \mathrm{MBq}$ ${ }^{109} \mathrm{Cd}$, or 10 to $17 \mu \mathrm{g} \mathrm{Cd} \mathrm{kg}{ }^{-1}$ body weight). The fish were then fed with uncontaminated food (chopped capelin) from Day 3 until the end of experiments.

The rate of water renewal in the aquariums was kept high enough (1.5 to $21 \mathrm{~min}^{-1}$ ) to approximate an open system with no recirculation of the metal. Water samples $(3 \mathrm{ml})$ were collected at least twice a week throughout the experiment and radioactivity was monitored for 10 min with a LKB Clinigamma counter. Radioactivity in all water samples was below the detection limit of $0.05 \mathrm{~Bq} \mathrm{ml}^{-1}\left(<0.5 \mathrm{ng} \mathrm{Cd}^{-1}\right)$.

${ }^{109} \mathrm{Cd}$ activity was repeatedly monitored over $42 \mathrm{~d}$ in the viscera and caudal muscle with an in vivo gamma counting system described elsewhere (Rouleau et al. 1998). Fish were anesthetized prior to radioactivity measurements and the $88 \mathrm{keV} \gamma$-ray emission of ${ }^{109} \mathrm{Cd}$ was monitored for 1 to $3 \mathrm{~min}$, daily during the first $7 \mathrm{~d}$ and then every 2 to $4 \mathrm{~d}$ thereafter. Fish did not appear to be affected by the repeated manipulations needed for gamma counting. They recovered from anesthesia within 15 min (recovery of equilibrium). One fish died during the experiment due to a technical failure that caused its aquarium to empty during the night.

${ }^{109} \mathrm{Cd}$ activity was quantified with Genie-PC Gamma Analysis software (Canberra-Packard). After corrections for background and decay, activity data were standardized by expressing them as a percentage of the activity measured at $t=0$. The stability of the gamma detector was regularly checked through the analysis of a standard containing $74 \mathrm{kBq}{ }^{109} \mathrm{Cd}$. The mean coefficient of variation of decay-corrected activities measured over the whole experimental period was $2.3 \%$, and the average statistical counting error was $1.4 \%$. The error due to variations in the positioning of fish under the detector, expressed as a coefficient of variation of 5 replicate measurements, was $2 \%$.

At the end of the experiments, all fish were sacrificed and dissected. Several tissues and organs were collected and their radioactivity measured. Data obtained were used to calculate the percentage of the ${ }^{109} \mathrm{Cd}$-body burden contained in each organ and tissue. The concentration index, $I_{\mathrm{C}}$ (Rouleau et al. 2000), was then calculated by: 


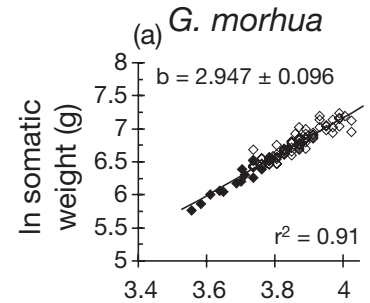

\section{R. hippoglossoides}

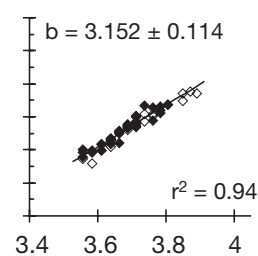

In size $(\mathrm{cm})$
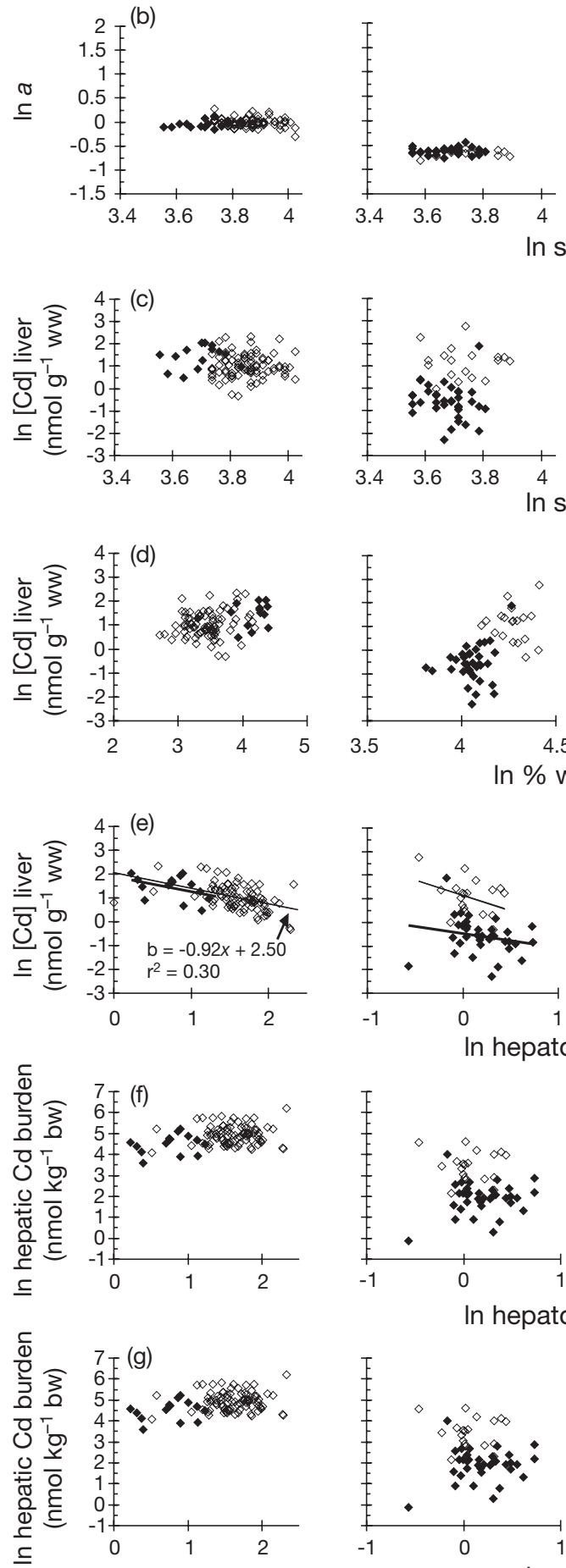

\section{H. platessoides}
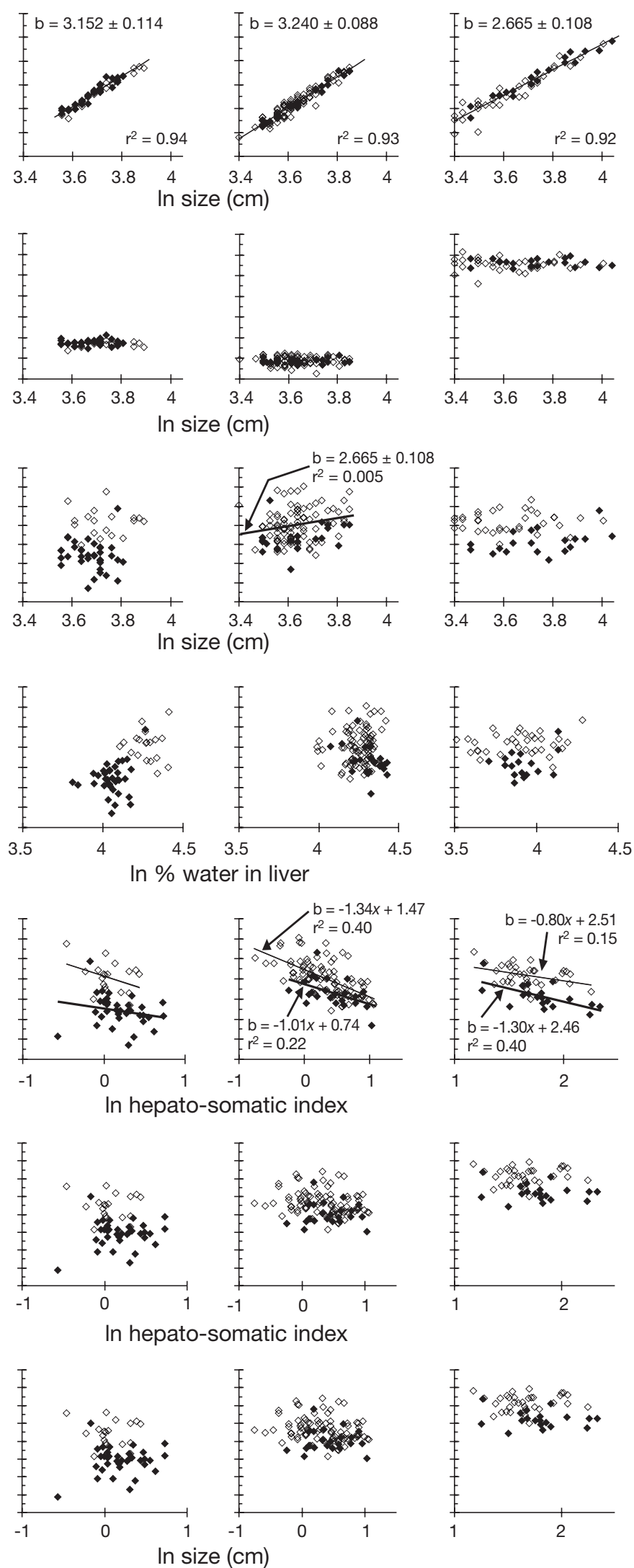

Fig. 2. Gadus morhua, Reinhardtius hippoglossoides, Hippoglossoides platessoides, and Raja radiata. (a) ln somatic weight vs. ln size, (b) ln a vs. ln size, (c) ln [Cd] in liver vs. ln size, (d) ln [Cd] in liver vs. ln \% water in liver, (e) ln [Cd] in liver vs. ln hepato-somatic index (HSI), (f) ln hepatic Cd burden vs. ln HSI, and (g) ln hepatic Cd burden vs. ln size. fish sampled from the

St. Lawrence Estuary; $\diamond$ : fish sampled from the Gulf; solid lines: result of linear regression (displayed when $p<0.05$ ) 
$I_{\mathrm{C}}=\frac{\% \text { of body burden }}{\% \text { of body weight }}=\frac{\left[{ }^{109} \mathrm{CD}\right] \text { in tissue }}{\left[{ }^{109} \mathrm{CD}\right] \text { in whole body }}$

A value of $I_{\mathrm{C}}>1$ indicates that a tissue is enriched in ${ }^{109} \mathrm{Cd}$ compared to the whole-body average metal concentration. Two additional American plaice, weighing ca. $50 \mathrm{~g}$, were each given $0.5 \mathrm{~g}$ of the ${ }^{109} \mathrm{Cd}$-contaminated food $\left(2.5 \mu \mathrm{g} \mathrm{Cd}\right.$ or ca. $50 \mu \mathrm{g} \mathrm{Cd} \mathrm{kg}^{-1}$ body weight) and sampled $7 \mathrm{~d}$ after feeding to be used for whole-body autoradiography, as described previously (Ullberg et al. 1982, Rouleau et al. 1998).

\section{RESULTS}

\section{Anatomical data}

Atlantic cod sampled in the Gulf were significantly larger than those sampled in the Estuary, whereas the reverse was the case for thorny skate. Weight-length relationships for the 4 fish species, as well as values of the calculated condition factor $a$ as a function of length, are shown in Fig. 2. No significant correlation could be found between $a$ and size for any of the fish species. Average values of a did not differ between sites for the Atlantic cod, American plaice, and thorny skate (Table 1). In the case of Greenland halibut, the difference between the Estuary and Gulf, though small, was significant.

Values of HSI and percentage of water in the liver strongly differed between sites for Atlantic cod (Table 1): the high value of HSI was associated with low water content in fish from the Gulf, whereas the inverse trend was observed for those sampled in the Estuary. A significant, though less marked, difference in liver water content was observed between sites for Greenland halibut and American plaice, but not for thorny skate (Table 1), and average values of HSI did not differ between sites for these 3 species. There was no significant difference in size between males and females for any of the fish species or sampling sites.

\section{Trends in hepatic cadmium concentration and burden}

The average concentrations of hepatic $\mathrm{Cd}$ were 2 to 5 times higher in Greenland halibut, American plaice, and thorny skate from the Gulf than in those sampled from the Estuary, whereas higher Cd concentrations were observed in the Estuary in the case of the Atlantic cod (Fig. 3). However, when expressing results as hepatic burden normalized for somatic body weight, all fish species exhibited the same trend, e.g. higher values in the Gulf than in the Estuary (Fig. 3). Hepatic

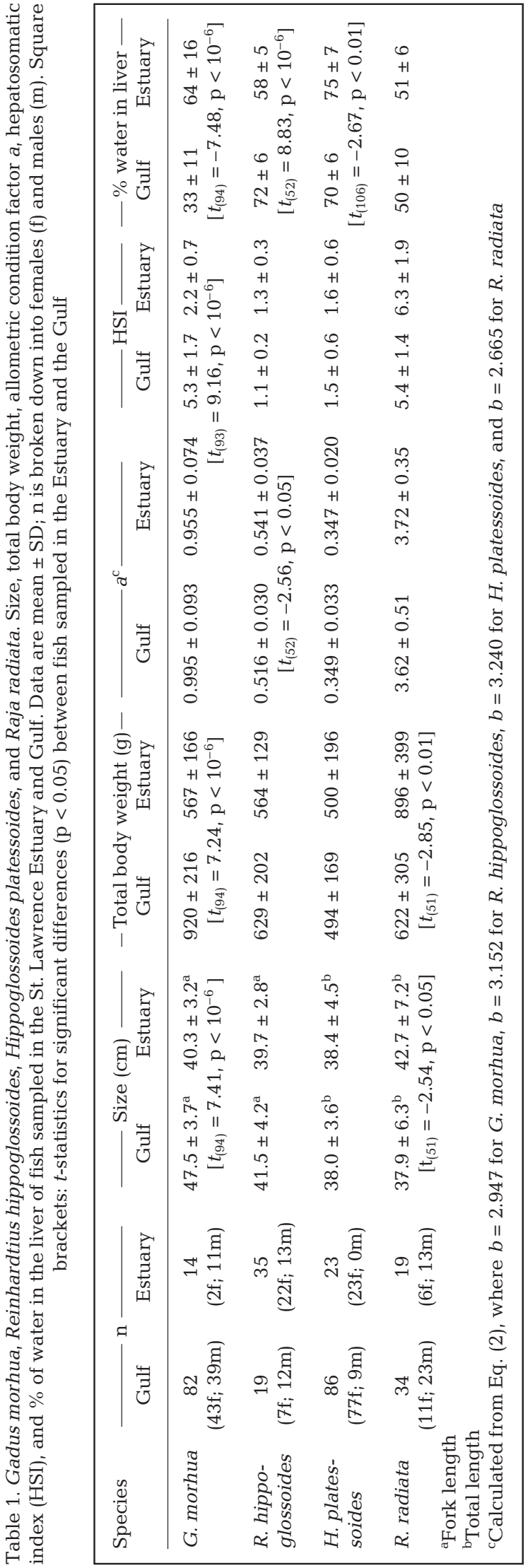



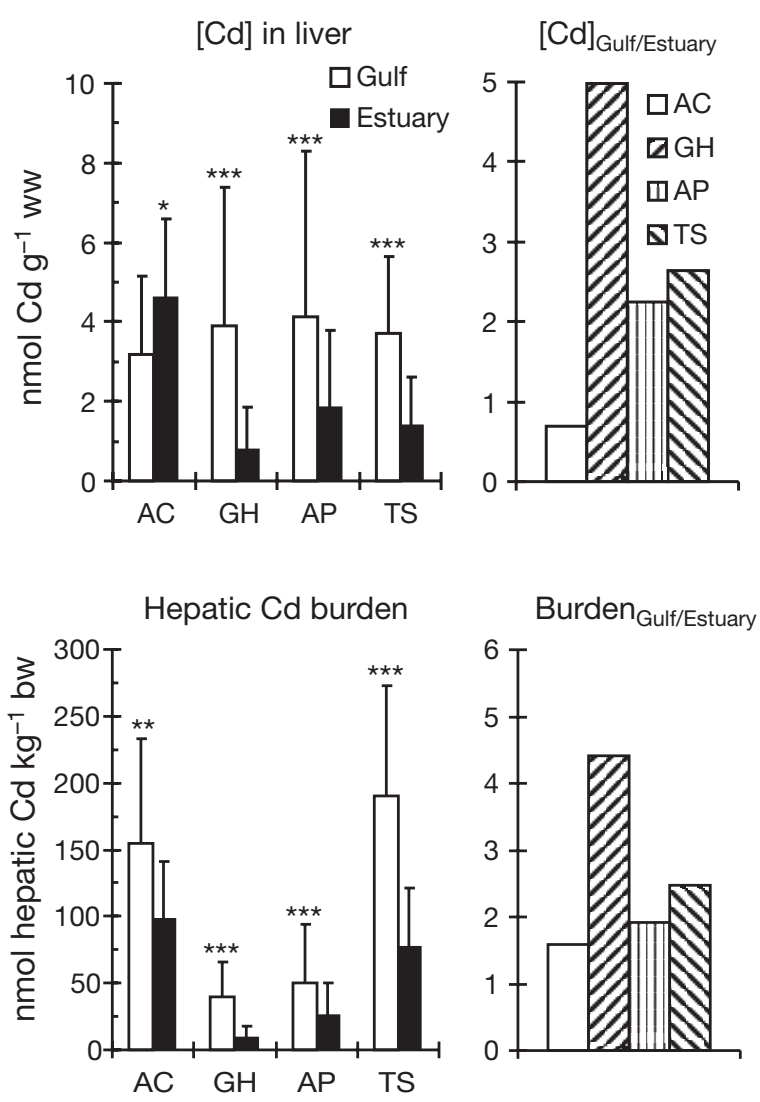

Fig. 3. Gadus morhua, Reinhardtius hippoglossoides, Hippoglossoides platessoides, and Raja radiata. Hepatic Cd concentration and hepatic Cd burden. Data are means $\pm \mathrm{SD}$. AC: Atlantic cod; GH: Greenland halibut; AP: American plaice; TS: thorny skate. Significant differences between sites at $\mathrm{p}<0.05, \mathrm{p}<0.01$ and $\mathrm{p}<0.001$ indicated by ${ }^{*},{ }^{* *}$, and ${ }^{* * *}$, respectively

Cd concentrations were not significantly correlated with size, with the exception of American plaice sampled from the Gulf (Fig. 2c) for which a very weak correlation was found. $\mathrm{Cd}$ concentrations were not correlated with the water content of the liver (Fig. 2d). A significant negative relationship between Cd concentration and HSI was observed for 5 of the 8 groups of fish (Fig. 2e). However, hepatic burden was not correlated with HSI, length (Fig. 2f,g), or water content (not shown).

Hepatic Cd concentrations did not differ between male and female with the exception of Atlantic cod in the Gulf $\left(3.7 \pm 2.2 \mathrm{nmol} \mathrm{g}^{-1} \mathrm{ww}\right.$ for males versus $2.7 \pm 1.6 \mathrm{nmol} \mathrm{g}^{-1}$ ww for females, $t_{(80)}=2.83, \mathrm{p}<0.01$ ). It is noteworthy that male fish had a smaller liver than females (male HSI $=4.8$ \pm 1.7 , female HSI $\left.=5.8 \pm 1.5, t_{(79)}=-3.25, \mathrm{p}<0.01\right)$, and that hepatic $\mathrm{Cd}$ burden of males and females did not differ (males $=167 \pm 91 \mathrm{nmol} \mathrm{kg}^{-1}$, females $=144 \pm$ $63 \mathrm{nmol} \mathrm{kg}^{-1}, t_{(79)}=1.31, \mathrm{p}=0.27$ ).

\section{Trends in sedimentary cadmium content and profiles}

Vertical extractable Cd and AVS profiles in the sediments were similar at all stations (Fig. 4). Concentrations extracted from the sediments with a diluted nitric acid solution were minimum at the sediment-water interface and then increased downwards below the depth corresponding approximately to the base of the enriched Mn surface layer. The average Cd concentration in the cores from the open Gulf was significantly higher $\left(\mathrm{p}<10^{-6}\right.$, non-parametric Mann-Whitney $U$-test) than in cores from the Estuary, with a Gulf/Estuary ratio of approximately 2 (Fig. 4). The concentrations of $\mathrm{Cd}$ extracted with nitric acid represented $85 \pm 8$ and $63 \pm 8 \%$ of the total Cd concentration in the Gulf and the Estuary, respectively.

\section{Biokinetics of dietary $\mathrm{Cd}$ in American plaice}

The ${ }^{109} \mathrm{Cd}$ activity in the caudal muscle of the American plaice remained too low to be detected by in vivo gamma counting, but was always well above the background in the viscera. A typical example of the temporal evolution of ${ }^{109} \mathrm{Cd}$ activity is illustrated in Fig. 5a. Activity sharply decreased at Day 3-4 as non-retained metal was eliminated with feces, and the quantity of retained ${ }^{109} \mathrm{Cd}$ decreased monoexponentially thereafter. Linear regression analysis of the natural logarithm of $\mathrm{Cd}_{t}\left({ }^{109} \mathrm{Cd}\right.$ activity at time $\left.t\right)$ allowed us to calculate the assimilation efficiency, $\mathrm{AE}_{0}\left(0 \% \leq \mathrm{AE}_{0} \leq\right.$ $100 \%$ ), and the first order elimination rate constant, $k_{\mathrm{e}}$ by:

$$
\ln \mathrm{Cd}_{t}=\ln \mathrm{AE}_{0}-k_{\mathrm{e}} t
$$

American plaice retained 8 to $27 \%$ of the Cd dose ingested and the biological half-life, $t_{1 / 2}$, of the retained metal varied between 57 and $131 \mathrm{~d}$ (Table 2).

Whole-body autoradiography showed that most of the radiolabel was concentrated in the gastrointestinal tract $7 \mathrm{~d}$ after feeding (Fig. 6). Detectable levels of radiolabel were also observed in the liver, but not in any other tissue. Data obtained by dissecting plaice at the end of the experiment did not reveal any marked changes in the distribution of ${ }^{109} \mathrm{Cd} 42 \mathrm{~d}$ after feeding, compared to results from the autoradiogram (Fig. 5). The gastrointestinal tract still accounted for most of the Cd body burden (Fig. 5b), with $94 \pm 3 \%$. The liver contained only $5 \pm 2 \%$, and the other tissues $\leq 0.3 \%$ each. The value of $I_{\mathrm{C}}$ (Fig. $5 \mathrm{c}$ ) was highest in the gastrointestinal tract $\left(I_{\mathrm{C}}=33 \pm 10\right)$, followed by the liver $\left(I_{\mathrm{C}}=3.4 \pm 2.3\right)$ and the other tissues $\left(I_{\mathrm{C}} \leq 0.5\right)$. 

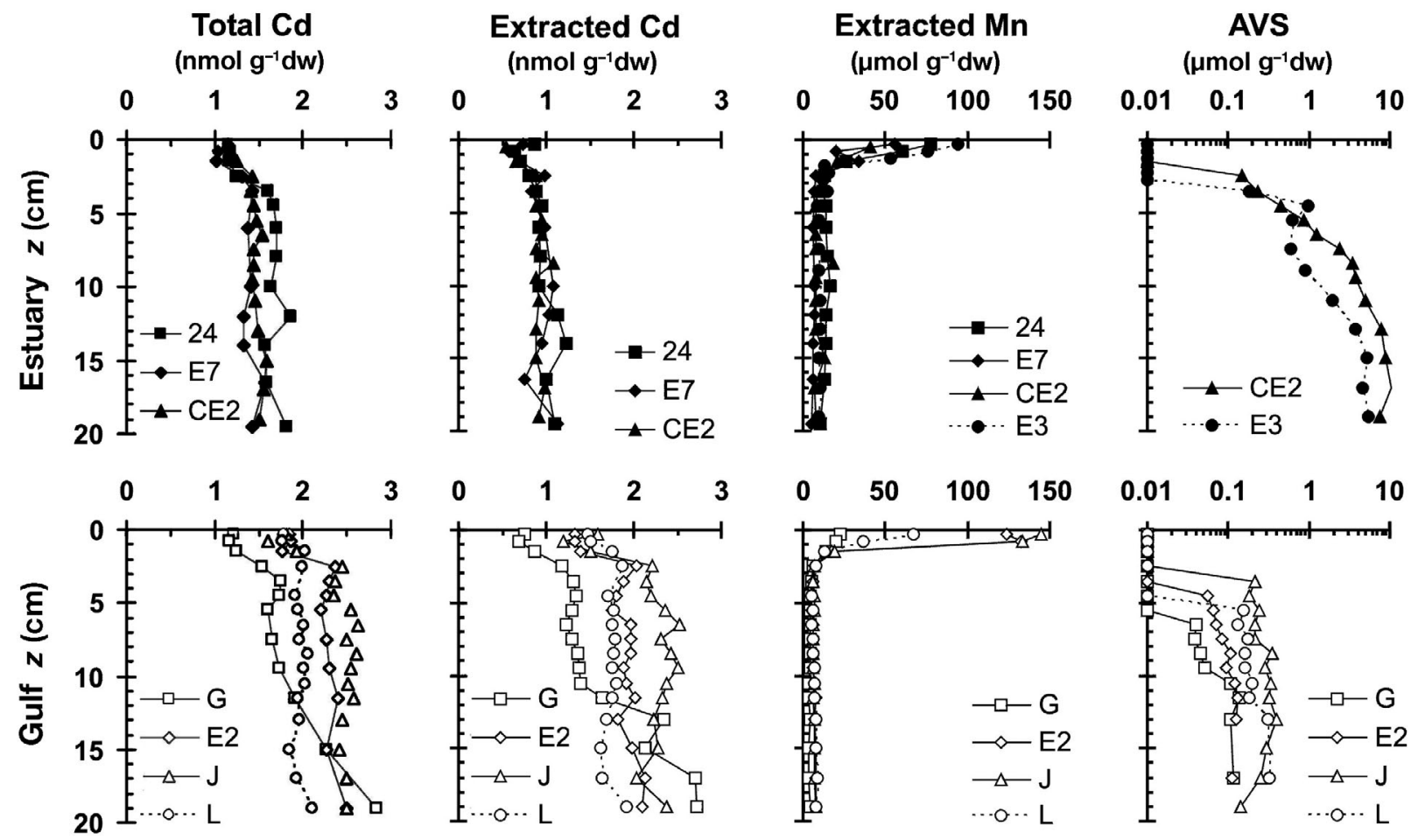

Fig. 4. Profiles of total sedimentary $\mathrm{Cd}$, extracted $\mathrm{Cd}$ and $\mathrm{Mn}$, and acid volatile sulfide (AVS) as a function of depth $z$ in sediment cores from the Estuary and Gulf of St. Lawrence. See Fig. 1 (solid squares) for location of sampling stations

Table 2. Hippoglossoides platessoides. Biokinetic parameters of dietary ${ }^{109} \mathrm{Cd}(\mathrm{II})$ in female American plaice. Values of elimination rate constant $k_{\mathrm{e}}$ and assimilation efficiency $\left(\mathrm{AE}_{0}\right)$ were determined by linear regression analysis with Eq. (4). Biological half-life $t_{0.5}$ is $\left(0.693 \mathrm{ke}_{\mathrm{e}}^{-1}\right)$ and the time needed to reach $95 \%$ of the kinetic equilibrium $t_{0.95}$ is $\left(2.996 k_{\mathrm{e}}^{-1}\right)$

\begin{tabular}{|c|c|c|c|c|c|}
\hline Fish no. & $\mathrm{AE}_{0}(\%)$ & $k_{\mathrm{e}}\left(10^{-3} \mathrm{~d}^{-1}\right)$ & $t_{0.5}(\mathrm{~d})$ & $t_{0.95}(\mathrm{yr})$ & $\mathrm{r}^{2}$ \\
\hline 1 & 10.0 & 12.1 & 57 & 0.7 & 0.92 \\
\hline 2 & 14.6 & 9.3 & 75 & 0.9 & 0.94 \\
\hline 3 & 26.7 & 5.3 & 131 & 1.6 & 0.74 \\
\hline 4 & 8.4 & 6.2 & 112 & 1.3 & 0.65 \\
\hline 5 & 24.0 & 7.9 & 88 & 1.0 & 0.78 \\
\hline $\begin{array}{l}\text { All fish } \\
(\text { mean } \pm S\end{array}$ & $\begin{array}{l}16.7 \pm 8.2 \\
\text { SD) }\end{array}$ & $8.2 \pm 2.7$ & $93 \pm 29$ & $1.1 \pm 0.4$ & \\
\hline
\end{tabular}

\section{DISCUSSION}

Hepatic $\mathrm{Cd}$ burdens of fish and $\mathrm{Cd}$ concentrations in sediments were both higher in the Gulf than in the Estuary, suggesting a direct causal relationship. This hypothesis, however, is subject to the following conditions: (1) that this trend reflects local conditions, (2) that sedimentary $\mathrm{Cd}$ is similarly bioavailable in the Gulf and the Estuary, and (3) that dietary $\mathrm{Cd}$ uptake in demersal fish is an efficient mechanism. Before such a conclusion can be drawn, variables such as morphological and physiological status of the fish relevant to the $\mathrm{Cd}$ content in tissues need to be carefully examined.

\section{Biological factors influencing cadmium content in fish}

The accumulation of a trace metal in a given species at a given location is dependent upon factors such as size, seasonal variations in physiological status, and sex (Depledge \& Rainbow 1990). The potential influence of these factors is discussed below. The discrepancy of the spatial trend observed for $\mathrm{Cd}$ concentration and body burden in the case of the Atlantic cod is of particular concern.

Relationships between weight and length, e.g. condition indices, are commonly used to compare the effect of biotic and abiotic factors on the health and well-being of a population (Cone 1989). The fact that no significant correlation could be found between the calculated values of the condition factor $a$ and size for any of the fish species (Fig. 2b) indicates that fish samples from the Estuary and Gulf were homogenous 

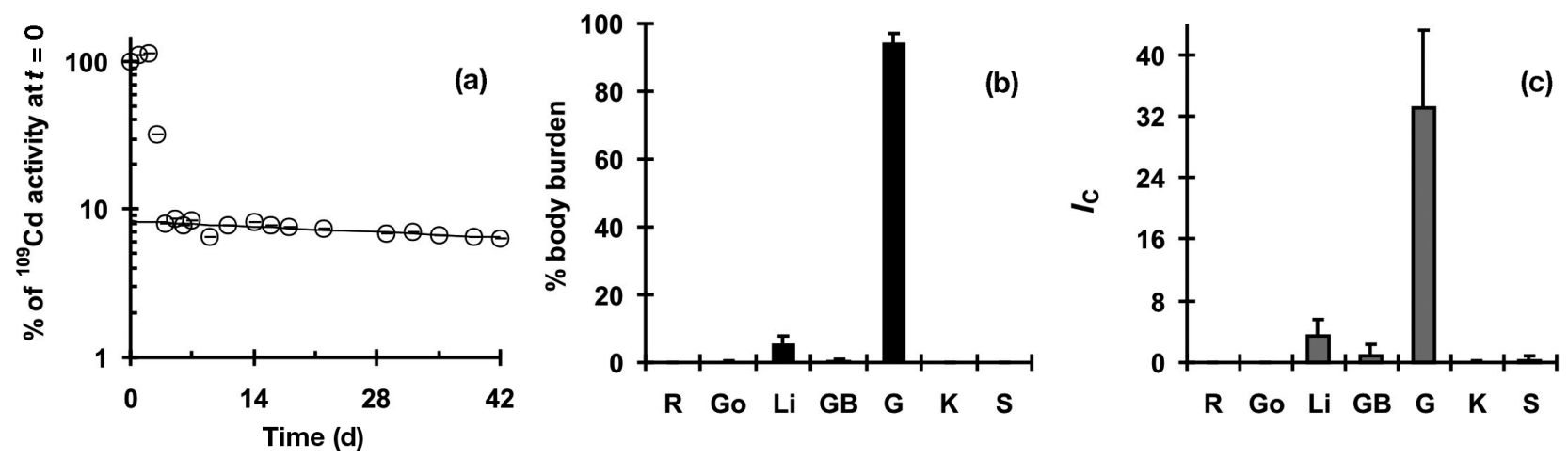

Fig. 5. Hippoglossoides platessoides. (a) Typical evolution of ${ }^{109} \mathrm{Cd}$ activity measured over $42 \mathrm{~d}$ in the viscera of female American plaice. Data are standardized as a percentage of the radioactivity measured immediately after feeding. Solid line represents the result of linear regression analysis with Eq. (4), excluding data from Day 0 to 3. (b) Percentage of ${ }^{109} \mathrm{Cd}$ body burden and (c) concentration index, $I_{\mathrm{C}}$, of various organs and tissues in plaice $(\mathrm{n}=5)$ dissected $42 \mathrm{~d}$ after feeding with ${ }^{109} \mathrm{Cd}$-contaminated food. Values are means $\pm \mathrm{SD}$. R: rest of body, Go: gonads, Li: liver, GB: gall bladder, G: gut, K: kidney, S: spleen

for $b$ (Eq. 2) in their weight-length relationship (Bolger \& Connolly 1989, Cone 1989). The similar values of condition factor a for Atlantic cod, American plaice, and thorny skate indicated that the 'fitness' of fish was similar, despite size differences observed for cod and skate (Table 1). In the case of Greenland halibut, the difference between Estuary and Gulf, though significant, was very small. It thus appears that the spatial distribution of hepatic $\mathrm{Cd}$ levels in fish cannot be related to variables of general health status. Furthermore, body size was not correlated with hepatic $\mathrm{Cd}$ concentrations, with the exception of American plaice (Fig. 2c) for which the correlation was very weak $\left(r^{2}=0.05\right)$.

The HSI and the percentage of water in the liver correlated well with the energy content of this organ (comprised mostly of fat), and accurately reflected the physiological status of many marine fish species (Lambert \& Dutil 1997, and references therein). In the case of Atlantic cod, the inverse spatial trends observed for HSI and water content were related to important seasonal variations in the nutritional status of this fish species (Lambert \& Dutil 1997, Schwalme \& Chouinard 1999). Lambert \& Dutil (1997) observed that cod caught in the St. Lawrence from August to January exhibited high HSI values, which characterized 'fat' livers, containing 40 to $70 \%$ lipid and $\leq 40 \%$ water. On the contrary, cod caught in May and June had low HSI values, characterizing 'lean' livers that typically contained $\leq 25 \%$ lipid and $\geq 60 \%$ water. These variations were strictly seasonal and not related to body size (Lambert \& Dutil 1997). In the present study, cod from the Gulf were caught in August and January, whereas those from the Estuary were caught in May (Table 1). Thus, the different physiological status of our 2 groups of cod, reflected by HSI and water content, was related to the time of their capture.

Variations in liver fat content may have had a significant impact on hepatic Cd concentrations since Cd in cells is mostly bound to proteins (George 1982). For a given hepatic $\mathrm{Cd}$ burden, an increase of liver size due to lipid accumulation will result in an apparent diminu-

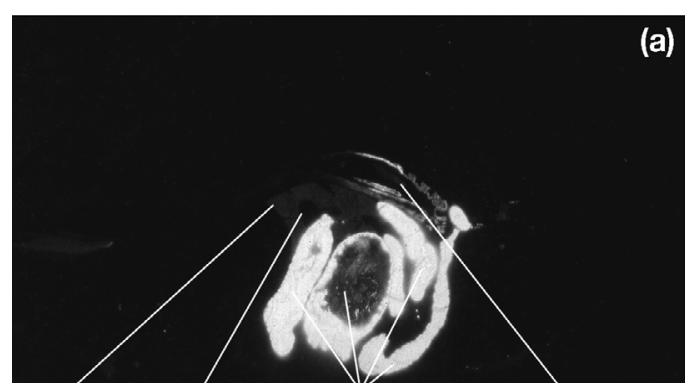

Liver Gallbladder Intestine Stomach
Brain Liver Spinal cord Blood Stomach Kidney

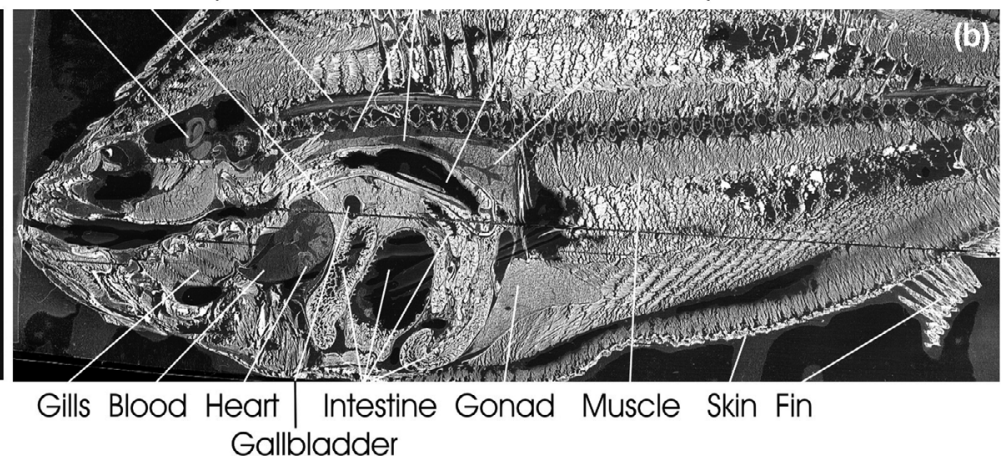

Fig. 6. Hippoglossoides platessoides. (a) Whole-body autoradiogram from an American plaice sampled $7 \mathrm{~d}$ after feeding with a single dietary dose of ${ }^{109} \mathrm{Cd}$. (b) Tissue section corresponding to (a) 
tion of $\mathrm{Cd}$ concentrations. In actual fact, the significant negative relationship between $\mathrm{Cd}$ concentration and HSI that was observed for most of the groups (Fig. 2e) was probably related to variations in the hepatic lipid content, since no significant correlation between $\mathrm{Cd}$ concentration and water content was found (Fig. 2d). This correlation between $\mathrm{Cd}$ concentration and HSI indicates that the comparison of hepatic Cd levels expressed as concentrations can be systematically biased. Relating metal concentration to the dry weight of the organ would not be useful in this case because dessication does not remove fat.

A more robust comparison was obtained by comparing hepatic $\mathrm{Cd}$ burden normalized for the somatic body weight. The absence of a correlation of hepatic Cd burden with HSI (Fig. 2f), length (Fig. 2g), and water content (not shown) demonstrated that the former was not affected by liver composition. As mentioned above, average hepatic $\mathrm{Cd}$ burdens were higher in the Gulf than in the Estuary for all 4 fish species (Fig. 3). The ratio [hepatic burden Gulf / hepatic burden $_{\text {Estuary }}$ ] for Greenland halibut, American plaice, and thorny skate was similar to the ratio observed for concentrations (Fig. 3).

In the case of the Atlantic cod, observed hepatic burden values revealed that fish from the Gulf contained $60 \%$ more $\mathrm{Cd}$ in their liver than those from the Estuary, despite seasonal changes in nutritional status that affected the apparent hepatic $\mathrm{Cd}$ concentration. The apparent discrepancy between concentration and hepatic burden data can be explained as follows: in addition to their effect on the value of HSI, seasonal variations in feeding rate were likely to also affect the hepatic Cd burden. The intake rate of the metal with food would vary with feeding rate, and if metal elimination rate by fish is deemed constant, the seasonal variations in the $\mathrm{Cd}$ hepatic burden would closely follow those of HSI. Fish from both the Gulf and the Estuary were submitted to the same seasonal pattern in feeding rate. This results in parallel temporal variations in HSI and Cd hepatic burden in both cod populations. Despite the fact that hepatic Cd burden of cod in the Gulf was always higher than in the Estuary, Cd hepatic concentrations may show an inverse spatial distribution sometime during the year if seasonal variations in HSI are more important compared to those affecting hepatic Cd burden. Fig. 7 shows a simulation of the seasonal variation of hepatic $\mathrm{Cd}$ concentration in standardized Atlantic cod of $600 \mathrm{~g}$ somatic body weight, in the case where variations of HSI $(3 \times)$ are greater than those affecting the hepatic $\mathrm{Cd}$ burden $(1.5 \times)$. Seasonal variations in the hepatic Cd burden were simulated with a kinetic model featuring cyclical feeding rates (Whicker \& Schultz 1982). The average hepatic burden values corresponded to those found in

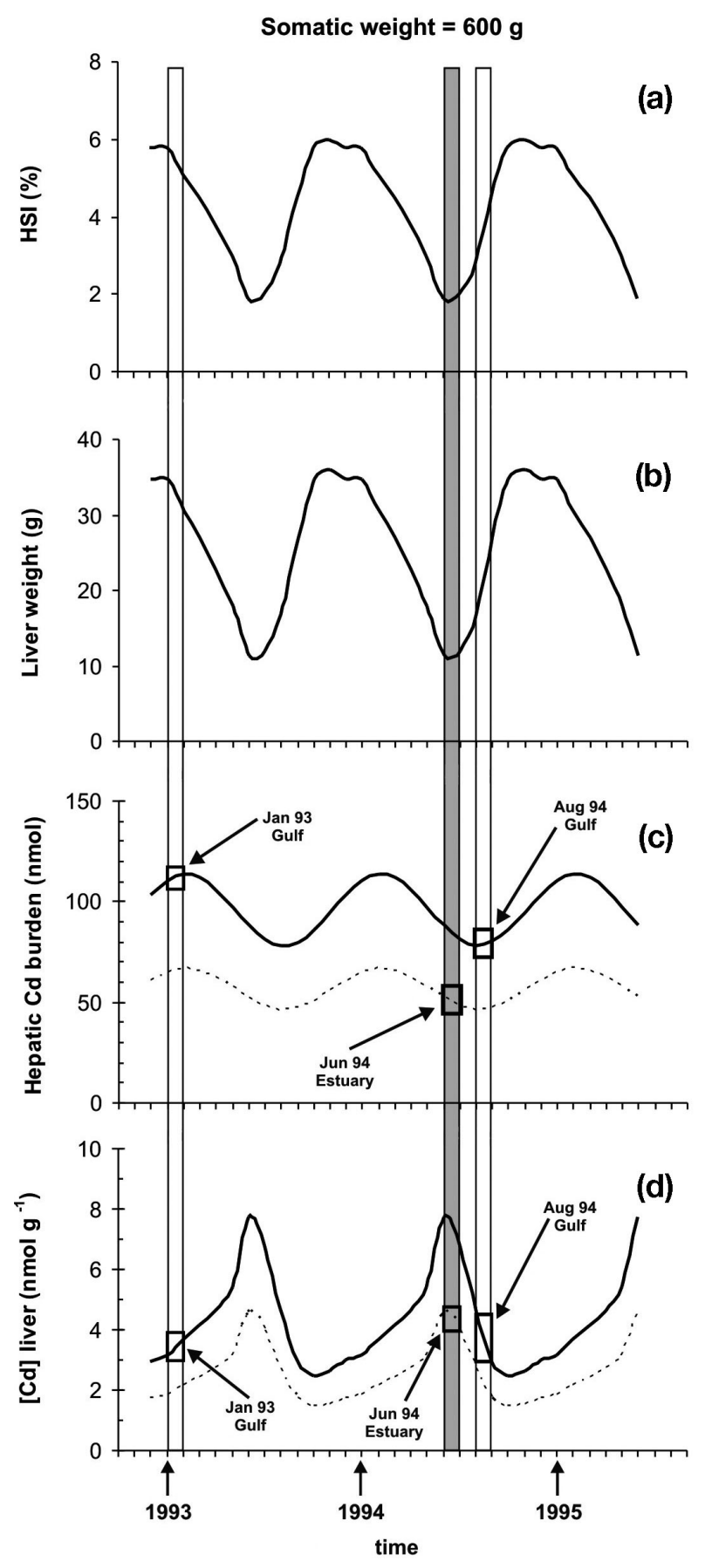

Fig. 7. Gadus morhua. Simulation of the seasonal variation of the hepatic Cd concentration in standardized Atlantic cod of $600 \mathrm{~g}$ somatic body weight, in the case where seasonal variations of HSI $(3 \times)$ are greater than those affecting the hepatic Cd burden $(<1.5 \times)$. (a) Seasonal variations of HSI interpolated from the data of Lambert \& Dutil (1997) and Schwalme \& Chouinard (1999). (b) The weight of the liver calculated according to Eq. (1). (c) Seasonal variations of the hepatic Cd burden simulated with a kinetic model featuring cyclical feeding rates (Whicker \& Schultz 1982). (d) Hepatic Cd concentrations (hepatic burden $\times$ liver weight ${ }^{-1}$ ). Shaded and open bars represent sampling in the St. Lawrence Estuary and Gulf, respectively 
wild fish caught in the Estuary and the Gulf of St. Lawrence. Despite the fact that hepatic Cd burden was always higher in fish from the Gulf (Fig. 7c), cod from the Estuary were sampled at a time when liver size was minimal. This resulted in higher hepatic $\mathrm{Cd}$ liver concentrations than cod from the Gulf, which were sampled at times when HSI values were high (Fig.7d). Hepatic Cd burden values can thus be considered a more reliable indicator of the Cd levels in the 4 fish species at the time of sampling than can hepatic concentrations.

From the above discussion, we can conclude that fish from the Gulf of St. Lawrence contained more $\mathrm{Cd}$ in their liver, expressed as hepatic burden, than fish from the Estuary, and this trend is not related to morphological, physiological, or seasonal factors.

\section{Cadmium pathways at the sediment-water interface}

The vertical distribution of sedimentary $\mathrm{Cd}$ was consistent with a mechanism whereby dissolved $\mathrm{Cd}$ diffuses downwards and precipitates with sulfide in anoxic sediments (Gobeil et al. 1987, 1997a, Pedersen et al. 1989, Rosenthal et al. 1995a,b). In Gulf sediments, AVS became detectable at a depth somewhat greater than the oxic-suboxic interface. Nevertheless, solubility calculations indicated that precipitation of CdS may occur in suboxic sediments in the presence of trace levels of sulfide that are below routine detection limits (Rosenthal et al. 1995b). Higher Cd concentrations in cores from the Gulf agreed with previous observations (Gendron et al. 1986, Gobeil et al. 1987, 1997a) and were due to lower sedimentation rates in the Gulf $\left(<1 \mathrm{~mm} \mathrm{yr}^{-1}\right.$ compared to 3 to $7 \mathrm{~mm}$ $\mathrm{yr}^{-1}$ in the Estuary; Smith \& Schafer 1999), which resulted in a less important dilution of authigenic $\mathrm{Cd}$ by Cd-poor terrigenous particles (Gendron et al. 1986). The fact that sedimentary Cd concentrations and hepatic $\mathrm{Cd}$ burden of fish were both higher in the Gulf than in the Estuary indicated that early diagenetic processes affect the bioaccumulation of $\mathrm{Cd}$, if sedimentary $\mathrm{Cd}$ is similarly bioavailable in the Gulf and the Estuary.

The bioavailability of authigenic Cd-sulfide is very low according to the AVS model. The latter states that free ionic divalent metal ions, including $\mathrm{Cd}^{2+}$, do not accumulate in porewater and are thus not bioavailable to endo- and epibenthic organisms when the molar ratio of metal simultaneously extracted with AVS is <1 (Di Toro et al. 1990, 1992, Carlson et al. 1991, Ankley 1996). However, though metal concentrations in porewater may be mostly controlled by equilibration with metal sulfides in sediments, benthic organisms are not exclusively exposed to dissolved metals as demonstrated by Lee et al. (2000a,b). These authors showed that dietary uptake controlled the accumulation of sedimentary $\mathrm{Cd}, \mathrm{Ag}, \mathrm{Ni}$, and $\mathrm{Zn}$ in the tissues of 4 species of filter- and deposit-feeding benthic invertebrates even if most metals in the diet were in sulfide forms. In actual fact, $\mathrm{Cd}$ concentrations in sediment-dwellers and deposit-feeders correlated well with sedimentary Cd extracted from sediments with a diluted acid solution (Thomas \& Bendell-Young 1998, Langston et al. 1999, Lee et al. 2000a,b, Wallace \& Luoma 2003, Wallace et al. 2003). Since we have determined Cd concentrations in the Laurentian Trough sediments by a method similar to those used in the above studies, e.g. cold weak acid treatment, it is likely that the bioavailability of $\mathrm{Cd}$ extracted from the sediments with diluted acid is roughly the same in both the Estuary and the Gulf. It is thus reasonable to suppose that $\mathrm{Cd}$ levels in benthic organisms of lower trophic level in the St. Lawrence were proportional to the level of extractable $\mathrm{Cd}$ in the sediments. The same would be true for predatory demersal fish if diet were the primary uptake route for $\mathrm{Cd}$.

\section{Modelling dietary cadmium uptake in American plaice}

The study of the biokinetics of dietary Cd in American plaice was aimed at the assessment of the actual importance of trophic transfer in this fish species. Since the distribution pattern observed in the American plaice $42 \mathrm{~d}$ after feeding (Fig. 5b,c) was not different from that seen in the autoradiogram obtained $7 \mathrm{~d}$ after feeding (Fig. 6), it appears that the distribution of assimilated ${ }^{109} \mathrm{Cd}$ reached a steady state within a few days after food ingestion. Both autoradiographic and quantitative data corresponded to the distribution observed in wild fish, with Cd concentrations in muscle and gonads that were very low compared to hepatic levels (Gobeil et al. 1997b).

The long-term accumulation of $\mathrm{Cd}$ in American plaice tissues was modeled with a simple 1-compartment model (Rouleau et al. 1998, 2000) expressed as:

$$
C_{\mathrm{p}}=C_{\mathrm{F}} \cdot \mathrm{AE}_{0} \cdot I_{\mathrm{C}} \cdot\left(k_{\mathrm{in}} / k_{\mathrm{e}}\right) \cdot\left(1-\mathrm{e}^{-k_{\mathrm{e}} t}\right)
$$

where $C_{\mathrm{P}}$ and $C_{\mathrm{F}}$ represent the concentrations of $\mathrm{Cd}$ in the predator's tissues and its food, respectively, and $k_{\text {in }}$ is the food consumption rate ( $\mathrm{g}$ food $\mathrm{g}^{-1}$ body weight $\mathrm{d}^{-1}$ ). Considering that the approximate age of the American plaice sampled during the field study, $>8$ yr (Scott \& Scott 1988), was higher than the time needed for dietary Cd uptake to reach $95 \%$ of the kinetic equilibrium (Table 2 ), we only modeled equilibrium $(t=\infty)$ hepatic Cd concentrations with: 
available and assimilated by predators (Wallace \& Lopez 1997, Wallace et al. 1998, Wallace \& Luoma 2003). Such a partitioning between available and nonavailable fractions does not occur in spiked food. Nevertheless, the good agreement between predicted and field concentrations and ranges strongly suggests that diet is the main source of $\mathrm{Cd}$ for the American plaice.

In summary, we demonstrated that the spatial distribution of hepatic Cd burden in the 4 fish species studied follows the distribution of sedimentary labile $\mathrm{Cd}$ concentrations in the Laurentian Trough. Higher Cd levels found in fish living in the Gulf of St. Lawrence corresponded to an enrichment of the Gulf sediments with authigenic $\mathrm{Cd}$. Though direct uptake of $\mathrm{Cd}$ from the sediment and water by demersal flatfish cannot be totally excluded at present, and further data are needed to better characterize their food sources in term of $\mathrm{Cd}$ concentration and speciation, the similarity between the laboratory-based predictions and Cd concentrations in wild American plaice strongly suggests that the correlation observed between hepatic $\mathrm{Cd}$ levels and extractable $\mathrm{Cd}$ in sediments is the result of trophic transfer.

Acknowledgements. This work was supported by the Toxic Chemicals Program of the Canadian Department of Fisheries and Oceans, and by the Swedish Foundation for Strategic Environmental Research. The authors gratefully acknowledge the technical assistance of Y. Clermont, L. Beaudin, J. Bolduc, A. Boström, and P. Robichaud.

\section{LITERATURE CITED}

Allen HE, Fu G, Deng B (1993) Analysis of acid-volatile sulfides (AVS) and simultaneously extracted metal (SEM) for the estimation of potential toxicity in aquatic sediments. Environ Toxicol Chem 12:1441-1453

Ankley GT (1996) Evaluation of metal/acid-volatile sulfide relationships in the prediction of metal bioaccumulation by benthic macroinvertebrates. Environ Toxicol Chem 15: 2138-2146

Arthur JR, Albert E (1993) Use of parasites for separating stocks of Greenland halibut (Reinhardtius hippoglossoides) in the Canadian northwest Atlantic. Can J Fish Aquat Sci 50:2175-2181

Bolger T, Connolly PL (1989) The selection of suitable indices for the measurement and analysis of fish condition. J Fish Biol 34:171-182

Campana SE, Chouinard GA, Hanson JM, Fréchet A (1999) Mixing and migration of overwintering Atlantic cod (Gadus morhua) stocks near the mouth of the Gulf of St. Lawrence. Can J Fish Aquat Sci 56:1873-1881

Carlson AR, Phipps GL, Mattson VR, Kosian PA, Cotter AM (1991) The role of acid-volatile sulfide in determining cadmium bioavailability and toxicity in freshwater sediments. Environ Toxicol Chem 10:1309-1319

Cone RS (1989) The need to reconsider the use of condition indices in fishery science. Trans Am Fish Soc 118:510-514

Cossa D (1988) Cadmium in Mytilus spp.: worldwide survey and relationship between seawater and mussel content. Mar Environ Res 26:265-284
Depledge MH, Rainbow PS (1990) Models of regulation and accumulation of trace metals in marine invertebrates. Comp Biochem Physiol C 97:1-7

Di Toro DM, Mahony JD, Hanson DJ, Scott KJ, Hicks MB, Redmond MS (1990) Toxicity of cadmium in sediments. The role of acid volatile sulfides. Environ Toxicol Chem 9: 1487-1502

Di Toro DM, Mahony JD, Hanson DJ, Scott KJ, Hicks MB, Redmond MS (1992) Acid volatile sulfide predicts the acute toxicity of cadmium and nickel in sediments. Environ Sci Technol 26:96-101

Gendron A, Silverberg N, Sundby B, Lebel J (1986) Early diagenesis of cadmium and cobalt in sediments of the Laurentian Trough. Geochim Cosmochim Acta 50:741-747

George SG (1982) Subcellular accumulation and detoxication of metals in aquatic animals. In: Vernberg WB, Calabrese A, Thurberg FP, Vernberg FP (eds) Physiological mechanisms of marine pollutant toxicity. Academic Press, New York, p 3-52

Gobeil C, Silverberg N, Sundby B, Cossa D (1987) Cd diagenesis in Laurentian Trough sediments. Geochim Cosmochim Acta 51:589-596

Gobeil C, Macdonald RW, Sundby B (1997a) Diagenetic separation of cadmium and manganese in suboxic continental margin sediments. Geochim Cosmochim Acta 61: 4647-4654

Gobeil C, Clermont Y, Paquette G (1997b) Concentrations en mercure, plomb et cadmium chez diverses espèces de poissons de fond, de poissons pélagiques et de crustacés de l'estuaire et du golfe du Saint-Laurent et du fjord du Saguenay. Rapp Stat Can Sci Halieut Aquat No. 1011

Hardisty MW, Huggins RJ, Kartar S, Sainsbury M (1974a) Ecological implications of heavy metal in fish from the Severn Estuary. Mar Pollut Bull 5:12-15

Hardisty MW, Kartar S, Sainsbury M (1974b) Dietary habits and heavy metal concentrations in fish from the Severn Estuary and Bristol Channel. Mar Pollut Bull 5:61-63

Horwood JW, Walker MG, Witthames P (1989) The effect of feeding levels on the fecundity of plaice (Pleuronectes platessa). J Mar Biol Assoc UK 69:81-92

Koutitonsky VG, Bugden GL (1991) The physical oceanography of the Gulf of St. Lawrence: a review with emphasis on the synoptic variability of the motion. In: Therriault JC (ed) The Gulf of St. Lawrence: small ocean or big estuary? Can Spec Publ Fish Aquat Sci 113:57-90

Lambert Y, Dutil JD (1997) Can simple condition indices be used to monitor and quantify seasonal changes in the energy reserves of Atlantic cod (Gadus morhua)? Can J Fish Aquat Sci 54(Suppl 1):104-112

Langston WJ, Burt RT, Pope ND (1999) Bioavailability of metals in sediments of the Dogger Bank (Central North Sea): a mesocosm study. Estuar Coast Shelf Sci 48:519-540

Lee BG, Griscom SB, Lee JS, Choi HJ, Koh CH, Luoma SN, Fisher NS (2000a) Influences of dietary uptake and reactive sulfides on metal bioavailability from aquatic sediments. Science 287:282-284

Lee BG, Lee JS, Luoma SN, Choi HJ, Koh CH (2000b) Influence of acid volatile sulfide and metal concentrations on metal bioavailability to marine invertebrates in contaminated sediments. Environ Sci Technol 34:4517-4523

Luoma SN, Rainbow PS (2005) Why is metal bioaccumulation so variable? Biodynamics as a unifying concept. Environ Sci Technol 39:1921-1931

McLaren MJ, Methven BA, Lam JWH, Berman SS (1995) The use of ICP-MS in the production of environmental certified materials. Mikrochim Acta 119:287-295

Morford JL, Emerson S (1999) The geochemistry of redox 
sensitive trace metals in sediments. Geochim Cosmochim Acta 63:1735-1750

Nakashima S, Sturgeon RE, Willie SN, Berman S (1988) Acid digestion of marine samples for trace element analysis using microwave heating. Analyst 113:159-163

Pedersen TF, Waters RD, Macdonald RW (1989) On the natural enrichment of $\mathrm{Cd}$ and molybdenum in the sediments of Ucluelet Inlet, British Columbia. Sci Total Environ 79: 125-139

Pentreath RJ (1977) The accumulation of cadmium by the plaice, Pleuronectes platessa L., and the thornback ray, Raja clavata L. J Exp Mar Biol Ecol 30:223-232

Provencher L, Bryl P, Gendron A, Roy F, Boyer J (1995) Essais d'alimentation de la morue franche (Gadus morhua). Rapp Tech Ind Sci Halieut Aquat No. 228

Ricker WE (1975) Computation and interpretation of the biological statistics of fish populations. Bull Fish Res Board Can 191:1-382

Rosenthal Y, Boyle EA, Labeyrie L, Oppo D (1995a) Glacial enrichments of authigenic Cd and U in Subantarctic sediments: a climatic control on the elements' oceanic budget? Paleoceanogr 10:395-413

Rosenthal Y, Lam P, Boyle E, Thomson J (1995b) Authigenic $\mathrm{Cd}$ enrichments in suboxic sediments: precipitation and postdepositional mobility. Earth Planet Sci Lett 132: 99-111

Rouleau C, Gobeil C, Tjälve H (1998) Pharmacokinetics and distribution of dietary tributyltin compared to those of methylmercury in the American plaice (Hippoglossoides platessoides). Mar Ecol Prog Ser 171:275-284

Rouleau C, Gobeil C, Tjälve H (2000) Accumulation of silver from the diet in two marine benthic predators: the snow crab (Chionoecetes opilio) and the American plaice (Hippoglossoides platessoides). Environ Toxicol Chem 19: 631-637

Schwalme K, Chouinard GA (1999) Seasonal dynamics in feeding, organ weights, and reproductive maturation of Atlantic cod (Gadus morhua) in the southern Gulf of St. Lawrence. ICES J Mar Sci 56:303-319

Scott WB, Scott MG (1988) Atlantic fishes of Canada. Can Bull Fish Aquat Sci No. 219

Editorial responsibility: Howard I. Browman (Associate Editor-in-Chief), Storebø, Norway
Smith JN, Schafer CT (1999) Sedimentation, bioturbation, and $\mathrm{Hg}$ uptake in the sediments of the estuary and Gulf of St. Lawrence. Limnol Oceanogr 44:207-219

Sundby B, Martinez P, Gobeil C (2004) Comparative geochemistry of molybdenum, cadmium, rhenium, and uranium in continental margin sediments. Geochim Cosmochim Acta 68:2485-2493

Swain DP, Chouinard GA, Morin R, Drinkwater KF (1998) Seasonal variation in the habitat associations of Atlantic cod (Gadus morhua) and American plaice (Hippoglossoides platessoides) from the southern Gulf of St. Lawrence. Can J Fish Aquat Sci 55:2548-2561

Thomas CA, Bendell-Young LI (1998) Linking the sediment geochemistry of an intertidal region to metal bioavailability in the deposit feeder Macoma balthica. Mar Ecol Prog Ser 173:197-213

Ullberg S, Larsson B, Tjälve H (1982) Autoradiography. In: Gleen HJ (ed) Biological applications of radiotracers. CRC Press, Boca Raton, FL, p 56-108

van Geen A, McCorkle DC, Klinkhammer GP (1995) Sensitivity of the phosphate-cadmium-carbon isotope relation in the ocean to cadmium removal by suboxic sediments. Paleoceanogr 10:159-170

Wallace WG, Lopez GR (1997) Bioavailability of biologically sequestered cadmium and the implications of metal detoxification. Mar Ecol Prog Ser 147:149-157

Wallace WG, Luoma SN (2003) Subcellular compartimentalization of $\mathrm{Cd}$ and $\mathrm{Zn}$ in two bivalves. II. Significance of trophically available metal (TAM). Mar Ecol Prog Ser 257: 125-137

Wallace WG, Lopez GR, Levinton JS (1998) Cadmium resistance in an oligochaete and its effect on cadmium trophic transfer to an omnivorous shrimp. Mar Ecol Prog Ser 172: 225-237

Wallace WG, Lee BG, Luoma SN (2003) Subcellular compartimentalization of $\mathrm{Cd}$ and $\mathrm{Zn}$ in two bivalves. I. Significance of metal sensitive fractions (MSF) and biologically detoxified metal (BDM). Mar Ecol Prog Ser 249:183-197

Whicker FW, Schultz V (1982) Radioecology: nuclear energy and the environment, Vol II, 1st edn. CRC Press, Boca Raton, FL

Submitted: March 21, 2005; Accepted: September 2, 2005 Proofs received from author(s): February 24, 2006 